\title{
Factors Associated with Visual Inspection Acetic Acid Examination at the Independent Medical Center of Doctor Aloysius
}

\author{
$1^{\text {st }}$ Elvine Ivana Kabuhung, $2^{\text {nd }} H$. Ali Rakhman Hakim \\ \{ $\underline{\text { elvineivana@gmail.com }}{ }^{1}$, alirakhamhakim@ unism.ac.id ${ }^{2}$ \}
}

Sari Mulia University, Banjarmasin

\begin{abstract}
Cervical cancer is the second highest reproductive organ disease in Indonesia with a prevalence of $0.8 \%$ in 2013. Early detection of cervical cancer is checked the method of Inspection Visual Acetic Acid (IVA) examination. IVA examination is an inexpensive and practical detection method. Data from the Central Kalimantan Provincial Health Office states that in 2014 and 2015 the achievement of IVA examinations was only $0.3 \%$ and $1 \%$. This study aims to analyze the factors associated with IVA examination using the Chi Square statistical test on 30 respondents with purposive sampling technique at the Independent Medical Center (IMC) of Doktor Aloysius. The results showed that the factors of attitudes, education, health insurance, and husband's support had a p value respectively were OR 0.003 ; $0.548 ; 0.712 ; 0.045 ; 95 \%$ CI. Based on these results was concluded that the factors of women's attitudes and husband's support are related to IVA examinations while the education and health insurance factors are not related to IVA examinations.
\end{abstract}

Keywords: Cervical Cancer, Acetic Acid Visual Inspection Examination, Attitude, Husband Support, Education, Health Insurance.

\section{Introduction}

Cervical cancer is a disease of the female reproductive organs with the secondhighest number of cases in women. The prevalence of cervical cancer in 2013 was around $0.8 \%{ }^{[1]}$. Cervical cancer is commonly found in developing countries, such as Indonesia. Cervical cancer is a significant problem in developing countries, where around $80 \%$ of cervical cancer cases occur each year. Cervical cancer ranks second out of all the number of cancers in women in Indonesia. Every year, more than 460,000 cases occur and around 231,000 women die from the disease ${ }^{[2,3]}$.

Cervical cancer detected early using the Inspection Visual Acetic Acid (IVA) method. IVA examination is very easy to do, inexpensive, require a short time and 
the results of the examination are immediately known. Even with all these advantages it is not easy to increase the achievement of targets for IVA examination in women. The Central Kalimantan Provincial Health Office recorded data from 7 cities / regencies (Palangka Raya City, Kotawaringin Timur Regency, Seruyan Regency, Katingan Regency, Pulang Pisau Regency, Kapuas Regency, and Murung Raya Regency) for 4 consecutive years. There were 827 women who had undertaken IVA examinations in 2014 out of 258,984 people $(0.3 \%)$ and in 2015 there were 1679 people out of 217,577 people (1\%). In 2016, IVA examinations are targeted to reach $20 \%$ of 330,861 women spread across 13 districts and 1 city in Central Kalimantan and in 2017 it is targeted to be $30 \%$ of 99,258 women, but the data for January 2017 to March 2017 results from IVA examinations in Central Kalimantan reached by $4.42 \% .{ }^{[4,5]}$

In an effort to improve the achievement of IVA examination targets in each district / city in Central Kalimantan, the Health Office trains health workers in each district / city to be able to conduct IVA examinations. One of the trained health workers was dr. Aloysius Yuwono Suprapta, who was directed directly by the South Barito District Health Office to attend the IVA examination training. Doctor Aloysius's Independent Medical Center (IMC) serves IVA examinations with the services of the Badan Penyelenggara Jaminan Sosial (BPJS) Kesehatan. Data from IMC Doctor Aloysius found that IVA examination outcomes were still low, namely 2 people in 2016 and 12 people in 2017 from January to August. Although socialization has been done about the importance of IVA examinations and IVA examination schedules, some women said they were embarrassed to do IVA examinations, some said they were worried about the high costs, some even said they had to consult their husbands first. ${ }^{[5]}$

\section{Research Methods}

This research uses analytic survey method with cross sectional design. The sample used as many as 30 people with a purposive sampling technique and analysis using the Chi-Square statistical test. The selected respondents were women who were eligible for an IVA examination. The study was conducted every Wednesday according to the schedule of IVA examination services at IMC Doctor Aloysius.

\section{Results}

\subsection{Univariate Analysis}

a. IVA Examination

Table 1. Frequency distribution of respondents based on IVA examination

\begin{tabular}{ccc}
\hline $\begin{array}{c}\text { IVA } \\
\text { Examination }\end{array}$ & $\mathrm{f}$ & $\%$ \\
\hline Are not do & 12 & 40 \\
\hline
\end{tabular}




\begin{tabular}{lcc}
\hline Do & 18 & 60 \\
\hline Amount & 30 & 100 \\
\hline
\end{tabular}

Table 1 were explained that $60 \%$ of respondents underwent IVA examination.

b. Attitude

Table 2. Frequency distribution of respondents based on attitude

\begin{tabular}{lcc}
\hline \multicolumn{1}{c}{ Attitude } & f & $\%$ \\
\hline Negative & 8 & 26,7 \\
\hline Positive & 22 & 73,3 \\
\hline Amount & 30 & 100 \\
\hline
\end{tabular}

Table 2 were explained that $73.3 \%$ of respondents have a positive attitude towards IVA examination

c. Education

Table 3. Frequency distribution of respondents based on education

\begin{tabular}{lcc}
\hline \multicolumn{1}{c}{ Education } & $\mathrm{f}$ & $\%$ \\
\hline High & 27 & 90 \\
\hline Low & 3 & 10 \\
\hline Amount & 30 & 100 \\
\hline
\end{tabular}

Table 3 were explained that $90 \%$ of respondents have a high level of education

d. Health Insurance

Table 4. Frequency distribution of respondents based on health insurance

\begin{tabular}{lcc}
\hline $\begin{array}{c}\text { Health } \\
\text { Insurance }\end{array}$ & $\mathrm{f}$ & $\%$ \\
\hline Do not have & 11 & 36,7 \\
\hline Have & 19 & 63,3 \\
\hline Amount & 30 & 100 \\
\hline
\end{tabular}

Table 4 were explained that $63.3 \%$ of respondents have health insurance.

e. Husband's Support

Tabel 5. Frequency distribution of respondents based on husband's support

\begin{tabular}{lcc}
\hline $\begin{array}{c}\text { Husband's } \\
\text { Support }\end{array}$ & $\mathrm{f}$ & $\%$ \\
\hline Does not support & 10 & 33,3 \\
\hline Support & 20 & 66,7 \\
\hline
\end{tabular}




\begin{tabular}{lll}
\hline Amount & 30 & 100 \\
\hline
\end{tabular}

Table 5 were explained that $66.7 \%$ of respondents received husband's support for conducting an IVA examination.

\subsection{Bivariate Analysis}

a. Correlation of Attitude with IVA Examination

Table 6. Cross table of attitude with IVA examination

\begin{tabular}{lccccccc}
\hline \multirow{2}{*}{ Attitude } & \multicolumn{4}{c}{ IVA examination } & \multicolumn{2}{c}{ Total } & \\
\cline { 2 - 6 } & \multicolumn{2}{c}{ No } & \multicolumn{2}{c}{ Yes } & & & \\
\cline { 2 - 6 } & $\mathrm{f}$ & $\%$ & $\mathrm{f}$ & $\%$ & $\mathrm{n}$ & $\%$ & P Value = \\
\hline Negative & 7 & 23,3 & 1 & 3,3 & 8 & 26,7 & 0,003 \\
\hline Positive & 5 & 16,7 & 17 & 56,7 & 22 & 73,3 & \\
\hline Amount & 12 & 40 & 18 & 60 & 30 & 100 & \\
\hline
\end{tabular}

Statistical test results between attitude and IVA examination obtained $\mathrm{p}$ value $=0,003$ means that it has correlation between attitude and IVA examination.

b. Correlation of Education with IVA Examination

Table 7. Cross table of education with IVA examination

\begin{tabular}{lccccccc}
\hline \multirow{2}{*}{ Education } & \multicolumn{4}{c}{ IVA examination } & \multicolumn{2}{c}{ Total } & \\
\cline { 2 - 6 } & \multicolumn{2}{c}{ No } & \multicolumn{2}{c}{ Yes } & & & \\
\cline { 2 - 6 } & $\mathrm{f}$ & $\%$ & $\mathrm{f}$ & $\%$ & $\mathrm{n}$ & $\%$ & P Value $=$ \\
\cline { 2 - 6 } Low & 2 & 6,7 & 1 & 3,3 & 3 & 10 & 0,548 \\
\hline High & 10 & 33,3 & 17 & 56,7 & 27 & 90 & \\
\hline Amount & 12 & 40 & 18 & 60 & 30 & 100 & \\
\hline
\end{tabular}

Statistical test results between education and IVA examination $\mathrm{p}$ value $=$ 0,548 means that were no correlation between education and IVA examination.

c. Correlation of Health Insurance with IVA Examination

Table 8. Cross table of health insurance with IVA examination

\begin{tabular}{lccccccc}
\hline \multirow{2}{*}{$\begin{array}{c}\text { Health } \\
\text { Insurance }\end{array}$} & \multicolumn{3}{c}{ IVA examination } & \multicolumn{2}{c}{ Total } & \\
\cline { 2 - 6 } & \multicolumn{2}{c}{ No } & \multicolumn{2}{c}{ Yes } & & & \\
\cline { 2 - 6 } & $\mathrm{f}$ & $\%$ & $\mathrm{f}$ & $\%$ & $\mathrm{n}$ & $\%$ & P Value $=$ \\
\hline No & 5 & 16,7 & 6 & 20 & 11 & 36,7 & 0,712 \\
\hline Yes & 7 & 23,3 & 12 & 40 & 19 & 63,3 & \\
\hline Amount & 12 & 40 & 18 & 60 & 30 & 100 & \\
\hline
\end{tabular}


Statistical test results between health insurance ownership and IVA examination obtained $\mathrm{p}$ value $=0,712$ means that were no correlation between health insurance ownership and IVA examination.

d. Correlation between Husband's Support with IVA Examination

Table 9. Cross table of husband's support with IVA examination

\begin{tabular}{lccccccc}
\hline \multirow{2}{*}{$\begin{array}{c}\text { Husband's } \\
\text { Support }\end{array}$} & \multicolumn{3}{c}{ IVA examination } & \multicolumn{2}{c}{ Total } & \\
\cline { 2 - 6 } & \multicolumn{2}{c}{ No } & \multicolumn{2}{c}{ Yes } & & & \\
\cline { 2 - 6 } No & 7 & 23,3 & 3 & 10 & 10 & 33,3 & 0,045 \\
\hline Yes & 5 & 16,7 & 15 & 50 & 20 & 66,7 & \\
\hline Amount & 12 & 40 & 18 & 60 & 30 & 100 & \\
\hline
\end{tabular}

Statistical test results between IVA examination with husband support obtained $\mathrm{p}$ value $=0,045$ meaning that it has correlation between IVA examination and husband support.

\section{Discussion}

\subsection{Relationship of Attitude and IVA Examination}

A positive attitude is an attitude that shows or shows, accepts, acknowledges, and approves the norms that apply where the individual is located, in this case IVA examination. The results of this study indicate there is a relationship between attitude and IVA examination. If someone behaves that cervical cancer does not cause a negative impact on themselves and their families then it does not trigger the person's awareness to do early detection of cervical cancer ${ }^{[6]}$. Factors that cause mothers not to undergo IVA examination include the presence of unfavorable attitudes such as embarrassment to have a check-up, feel no need to check themselves and feel the IVA test is not important. This is consistent with the theory that attitudes are formed by the interaction experienced by individuals. This interaction contains a deeper meaning so that there is a relationship that affects each other between individuals, also with the physical environment and the surrounding psychological environment ${ }^{[7]}$.

\subsection{Relationship of Education with IVA Examination}

High School and Higher Education is a tertiary level of education. Higher education is education that prepares students to become members of society who have academic and professional skills so that they can apply, develop and / or create science, technology, and art in the framework of national development and improve human welfare ${ }^{[8]}$. The results showed that there was no relationship between education and IVA examination. This study is in line with the results of research conducted by Istiqomah Risa, namely there is no significant relationship between maternal education and IVA examination participation ${ }^{[9]}$. Higher 
education makes it easier for someone to get information from print, electronic, health workers, family and friends. High school education includes high school level so that one will be easy to obtain information including information about health that gives effect to people's attitudes and practices in maintaining and improving their own health. Kurniawati explained in her study that women with low levels of education did not get enough information about the early detection of cervical cancer. Conversely, women with secondary and tertiary education will get information about cervical cancer through various information media, but all will return to the awareness of each individual in addressing their own health ${ }^{[10]}$.

\subsection{Relationship of Health Insurance with IVA Examination}

Regulation of the Minister of Health of the Republic of Indonesia Number 28 of 2014 concerning Guidelines for the Implementation of National Health Insurance explains that all Indonesian people are participants of national health insurance ${ }^{[11]}$. In the results of this study found that the majority of respondents have health insurance but there are still respondents who do not have health insurance. The results of the study also found that there was no relationship between health insurance with IVA examination. The results of this study are the same as the results of research conducted by Nuur, namely there is no relationship between health insurance with the visit of the IVA / Pap Smear examination ${ }^{[12]}$. IVA examination is a method of visual inspection of the cervix by applying 3-5\% acetic acid liquid. This method is a practical, inexpensive, and most possible method for screening cervical cancer in Indonesia. Based on the results of the study it can be seen that although they do not have health insurance (20\%), there are still those who do IVA examinations. This shows that ownership of health insurance is not an important factor for conducting an IVA examination. Health insurance ownership is related to costs, the cost of IVA examinations is predicted to be around Rp 100,000, meaning that some women have no problem with costs, but there are other factors that encourage women to carry out IVA examinations despite having to pay.

\subsection{Relationship of Husband's Support and IVA Examination}

The results of this study indicate that there is a relationship between husband's support and IVA examination. Most women do IVA examinations because they are supported by their husbands and if the husband does not support the women do not do IVA checks. Husband's support is an important factor to encourage women to do VIA. The results of research conducted by Wahyuni explained that the support of the husband helps his wife to make an effort to live a healthy life, reduce fear of the results of health checks that will be faced, and restore confidence to the wife if experiencing problems with her health ${ }^{[13]}$. Likewise, the results of research conducted by Suyami stated that husband's support had an impact on women's participation in IVA examinations ${ }^{[14]}$.

\section{Conclusion}


Based on the results of the study it can be concluded that the factors of woman's attitude and husband's support are related to IVA examination. Whereas education and health insurance factors are not related to IVA examination. The results of this study can be a continuation in subsequent studies, namely knowing the most dominant factor related to IVA examination.

\section{References}

[1] Kementerian Kesehatan RI. InfoDatin, Pusat Data dan Informasi Kementerian Kesehatan RI. Jakarta: Departemen Kesehatan RI. (2015)

[2] Kementerian Kesehatan RI. Buku Acuan Pencegahan Kanker Payudara dan Kanker Leher Rahim. Jakarta: Departemen Kesehatan RI. (2016)

[3] Kementerian Kesehatan RI. Pedoman Teknis Pengendalian Kanker Payudara dan Kanker Leher Rahim. Jakarta: Departemen Kesehatan RI. (2016)

[4] Dinas Kesehatan Provinsi Kalimantan Tengah. Profil Kesehatan 2014 Provinsi Kalimantan Tengah. Palangka Raya: Dinas Kesehatan Provinsi Kalimantan Tengah. (2014)

[5] Dinas Kesehatan Provinsi Kalimantan Tengah. Penanggulangan dan Deteksi Kanker pada Perempuan Dalam Rangka Hari Kartini dan HUT Kalteng, dalam Surat Edaran DInas Kesehatan Provinsi Kalteng. Palangka Raya: Dinas Kesehatan Provinsi Kalimantan Tengah. (2017)

[6] Susanti, Aris. Faktor-faktor yang Berhubungan dengan Rendahnya Kunjungan Inspeksi Visual Asam Asetat (IVA) di Wilayah Kerja Puskesmas Halmahera Kecamatan Semarang Timur. Semarang: Jurusan Ilmu Kesehatan Masyarakat Fakultas Ilmu Keolahragaan Universitas Negeri Semarang. (2011)

[7] Notoatmodjo, Soekidjo. Ilmu Perilaku Kesehatan. Jakarta: PT Rineka Cipta. (2010)

[8] Ahmadi, Abu. Uhbiyati, Nur. Ilmu Pendidikan. Jakarta: Rineka Cipta. (2008)

[9] Risa, Istiqomah. Keikutsertaan IVA Test Dilihat dari Pengetahuan dan Pendidikan Ibu di Kelurahan Keden. Surakarta: Prosiding Nasional APIKESAKBID Citra Medika Surakarta. (2015)

[10] Kurniawati, W. Aini, F. Maryanto, S. Faktor-faktor yang Berhubungan dengan Perilaku WUS dalam Melakukan Deteksi Dini Kanker Serviks dengan Metode Inspeksi Visual Asam Asetat (IVA) di Wilayah Kerja Puskesmas Kretek Bantul Yogyakarta. Tesis. Yogyakarta: STIKes Ngudi Waluyo Yogyakarta. (2015)

[11] Kementerian Kesehatan RI. Peraturan Menteri Kesehatan Republik Indonesia Nomor 28 Tahun 2014 tentang Pedoman Pelaksanaan Jaminan Kesehatan Nasional. Jakarta: Kementerian Kesehatan Republik Indonesia. (2014)

[12] Nuur. 2015. Faktor-faktor yang Berhubungan dengan Kunjungan Pemeriksaan IVA/ Pap Smear pada Ibu-ibu PKK di Dusun Tajem Depok Sleman. Skripsi Program Studi Bidan Pendidik Jenjang Diploma IV Sekolah Tinggi Ilmu Kesehatan 'Aisyiyah Yogyakarta. (2015)

[13] Wahyuni. Sikap Suami Berhubungan dengan Motivasi Istri dalam Melakukan Pengobatan Suatu Penyakit. Motorik, Volume 12 Nomor 24, Februari 2017. (2013)

[14] Suyami. Dampak Dukungan Suami Terhadap Partisipasi Pemeriksaan Inspeksi Visual Asam Asetat (IVA) pada Ibu Usia Subur di Puskesmas Trucuk II Klaten. Motorik, Volume 12 Nomor 24, Februari 2017. (2017) 